\title{
Editorial
}

Rosimeri de Oliveira Dias

Heliana de Barros Conde Rodrigues

DOI: 10.12957/mnemosine.2020.52676

Parte especial: Dossiê Formação inventiva de professores: ensaios microfísicos, pesquisa-intervenção e estudos foucaultianos.

Desde o ano de 2009 acontece na Faculdade de Formação de Professores de São Gonçalo da Universidade do Estado do Rio de Janeiro (FFP/UERJ) uma série de trabalhos sobre formação inventiva de professores em interface com estudos foucaultianos, pesquisa-intervenção com escolas parceiras e ensaios ético-estético-políticos. Nesta mesma perspectiva - a de historicizar e celebrar modos de trabalhar uma formação outra -, o presente dossiê convida a uma conversa com intercessores que também empreendem essa covizinhança.

Um certo princípio - nada "principista" ou moralizante, por sinal - move uma formação inventiva: manter vivo um campo problemático. Neste sentido, uma interrogação principal é afirmada/reafirmada neste dossiê: como não esgotar os processos formativos em didáticas apriorísticas, que reduzem a formação à ideia de 'dar forma a'?

Contrária a tal posição - exatamente a de 'dar forma a' -, uma formação inventiva se coloca como formação experiência. Construída, entre outros dispositivos do pensar, por meio das políticas de cognição, dos estudos de produção de subjetividade, da análise institucional, da micropolítica, de uma estética da existência e da pesquisa-intervenção, uma formação inventiva habita os territórios da formação - universidade e escola básica, notadamente - para forjar modos outros de estudar, de conversar, de estar nos territórios.

Os artigos que compõem o dossiê, nesta linha, visualizam possibilidades de formar que escapem a lógicas capacitadoras e pedagogizantes, aqui entendidas como aquelas que se dão como aplicação de saberes prévios, generalizantes. Pois há, na formação inventiva, modos de agir que não convidam o pensamento ao exame, ao julgamento, à manutenção de modelos; modos que, diferentemente, forçam o pensamento a pensar e se propõem como um aprender infinito. Nesta dimensão problematizadora, a formação inventiva comparece, paradoxalmente, na escola e na universidade, excedendo os estados perceptivos do vivido habitual. Pode, assim, acontecer como um esforço por liberar a 
vida lá onde ela é/está aprisionada, facultando deslocamentos quanto aos modelos representacionais, reféns (ou seriam carcereiros?) da vontade de verdade.

Com isso se abre um composto problemático que vibra para tecer uma experiência. E cumpre lembrar que para Michel Foucault, intercessor contumaz, experiência é algo de que se sai transformado. No momento de apresentação deste dossiê, não poderíamos deixar de colocar em cena a experiência presente de todos nós, por mais que também marcada por irrecusáveis diferenças: a pandemia do Covid-19. Com efeito, o isolamento social com ela imposto nos posicionou em territórios de trabalho dentro de casa: aulas, orientações, pesquisas, ou seja, encontrar e conversar, hoje ganham contorno remoto.

Mas o princípio de uma formação inventiva - manter vivo um campo problemático - permanece fundamental nestes dias de reclusão e distanciamento. Com ele, reavivamos permanentemente as seguintes perguntas: como pensar o presente?; como elementos e atores desse presente - inclusive, embora não exclusivamente, na qualidade de formadores -, o que estamos fazendo, contemporaneamente, de nossas vidas?

Se ser contemporâneo significa, como sugere Agamben, perceber no escuro do presente as linhas de visibilidade e enunciação que procuram nos alcançar e eventualmente não podem fazê-lo, vale correr o risco de afirmar que o contemporâneo é, antes de tudo, questão de coragem. Consiste em ser capaz não apenas de manter fixo o olhar no escuro da época - a pandemia-pandemônio que, de múltiplas maneiras, nos tem atravessado -, mas também de perceber neste escuro as subjetivações emergentes que, dirigidas a nós, distanciam-se infinitamente de nós. Ser contemporâneo é, portanto, algo que nos coloca em compromisso-tensão permanente com o tempo presente e que o transforma. Sendo assim, o sentido de contemporâneo que atravessa nossa discussão sobre formação inventiva não é aquele que se limita ao vivido do presente, mas o que, por não coincidir com este presente, nele apreende, embora de forma fugaz, as linhas de luz, de enunciação e de subjetivação capazes de deslocá-lo para/com outros tempos.

Um conceito que também habita os textos que compõem o dossiê é o de resistência. Nós o tomamos no sentido deleuziano, o que o faz escapar ao binarismo zero/um - haver, ou não, resistência - e colocar-se como a afirmação de uma diferença pela arte. Arte como aquilo que resiste, que pode fazer ver e falar, tornar visível e enunciável, fazer a obra ficar de pé sozinha. Em tal perspectiva, a ideia de contemporâneo e a de resistência funcionam a favor daquilo que força o pensamento a pensar e a operar pelo que pode inventar a vida, inclusive (ou especialmente) a vida formativa, de modos outros: invenção e constituição, portanto, de uma série múltipla de subjetividades 
infinitas, dando acesso à diferença como possibilidade de alteridade, de estranhamento de si, do outro e do mundo.

Talvez, na contramão do momento atual - o qual clama por normas e direitos que, embora eventualmente progressistas, modulam relações, instituindo a fixidez das soluções definitivas que imprimem imensa imobilidade ao fazer e ao pensar -, seja possível habitar os espaços e tempos formativos fazendo deles territórios de pensamentos problematizadores, que prescindem de porta-vozes institucionais. Porque formandos e formadores decerto podem falar por si mesmos, constituindo suas próprias tessituras experienciais, resistindo e movendo a vida lá onde ela....acontece.

\section{Parte geral:}

Apesar do isolamento social ou, eventualmente, em decorrência dele, continuamos a receber inúmeros artigos, no caso voltados à parte geral; particularmente, muitos artigos em que Michel Foucault comparece como ferramenta analítica de destaque. Além do mais, duas traduções integram a presente edição: a primeira, de um artigo do sociólogo francês Bruno Karsenti voltado à análise das relações entre poder e subjetivação em Michel Foucault; a segunda, de um capítulo do livro O Estado Inconsciente, de René Lourau, também sociólogo, também francês, mas, principalmente, "analista institucional em tempo integral", como gostamos de chamá-lo. Embora pouco sólidas na perspectiva de uma história meramente factual, as articulações entre Foucault e Lourau nos interessam sobremaneira, principalmente num momento como o atual, em que as relações entre instituições e poder, indicadores e analisadores, parresía e análise de implicações, política e ética parecem tão fecundas para provocar o pensamento... a pensar.

Muita gente partiu num rabo de foguete nos últimos meses. Entre tantas pessoas, entre tantas "uma vida", um carioca que soube como ninguém cantar os e as infames. Como conchas à beira-mar, fragmentos biográficos de Aldir Blanc se espalham nas páginas virtuais de Mnemosine e nos convocam ao aplauso - aplauso ao próprio Aldir e também àquele que bem sabe o quanto Aldir cabe bem em uma revista que se dedica à história e à memória de uma certa psicologia: “As práticas de vida cantam, as lógicas de morte calam".

Obrigada, autores e pareceristas, por mais esta.

Obrigada, Simone, pelo cuidado de sempre.

Aos leitores, um novo convite à indocilidade refletida. 